Andrzej Tokarski, Marek Matuszak

Wyższa Szkoła Bankowa w Toruniu, Polska - School of Banking in Torun, Poland

\title{
Upadłość jako instytucja gospodarki rynkowej
}

\author{
Bankruptcy as an Institution of the Market Economy
}

\begin{abstract}
Streszczenie: Upadłość to jedna z najważniejszych instytucji gospodarki rynkowej. Działająca prawidłowo zapewnia efektywną alokację środków produkcji i ochronę wierzycieli. Pojęcie instytucji jest wieloznaczne. W niniejszym artykule przedstawione zostanie znaczenie tego terminu w rozumieniu nadawanym mu zarówno w tzw. nowej ekonomii instytucjonalnej, jak i w znaczeniu tradycyjnym. Instytucje upadłości obejmują nie tylko regulacje prawne określające obowiązujące procedury, lecz także cały aparat zapewniający osiąganie celów postępowań upadłościowych, na który składają się sędziowie orzekający w sprawach upadłościowych, syndycy zarządzający masą upadłości, nadzorcy sądowi i zarządcy, jak również w znaczeniu szerszym, nawiązującym do nowej ekonomii instytucjonalnej, zakorzenione w danym społeczeństwie „podejście” do zjawiska upadłości przedsiębiorstw. Upadłość przedsiębiorstw stanowi nieodłączny dla gospodarki rynkowej mechanizm selekcji nieefektywnych podmiotów gospodarczych. W tym znaczeniu upadłość przedsiębiorstw uznawać można za zjawisko pozytywne i potrzebne, co jednak nie oznacza, że upadłość nie pociąga za sobą również szeregu negatywnych konsekwencji. Tak więc problemem jest nie samo zjawisko upadłości, lecz sposób zorganizowania szeroko rozumianej sfery infrastruktury instytucjonalnej, od której w dużej mierze zależą charakter, skuteczność i zakres zarówno pozytywnych, jak i negatywnych następstw praktycznie dla wszystkich stron (interesariuszy, uczestników) procesów upadłościowych. Celem artykułu jest przedstawienie wybranych problemów instytucji upadłości w warunkach polskiej gospodarki rynkowej na podstawie obowiązujących w tym zakresie do $2015 \mathrm{r}$. regulacji prawnych. Przy pisaniu artykułu wykorzystane zostały dwie podstawowe metody badawcze: analiza danych zastanych, tzn. obowiązujących przepisów prawa dotyczących upadłości przedsiębiorstw w Polsce, oraz analiza literatury przedmiotu dotyczącej instytucji upadłości.
\end{abstract}

Abstract: Bankruptcy is one of the most important institutions of the market economy. Properly constructed and implemented normatively and institutionally it ensures effective protection of creditors and efficient allocation of production. Institutions of bankruptcy include not only regulations providing guidance on the procedure, but also the entire apparatus to fulfill the objectives of the insolvency proceedings, which consists of judges on bankruptcy, auditors managing the bankruptcy estate, the supervisor and court administrators, the banking sector rescuing financial entrepreneurs falling into trouble, but also and above all an entrepreneur.Bankruptcy is an integral market economy mechanism for the selection of inefficient operators. The problem is not that bankruptcy occurs, but that the economic system is not properly prepared. It is expressed primarily in a broad sense in a lack of institutional infrastructure of bankruptcy.This article presents the analysis of literature and applicable laws of the institution of 
bankruptcy and its components. The basic method used is the analysis of existing data - existing legislation relating to bankruptcy of enterprises in Poland, and analysis of the literature on bankruptcy as an institution functioning in the market economy, taking into account the Polish economy.

Słowa klucze: infrastruktura upadłości; instytucja upadłości; modele upadłości; podmioty (interesariusze) postępowania upadłościowego; upadłość; upadłość w polskiej gospodarce

Key words: bankruptcy; bankruptcy institution's models; bodies of insolvency proceedings; infrastructure of bankruptcy; institution of bankruptcy; bankruptcy in the Polish economy

Otrzymano: 5 listopada 2015

Received: 5 November 2015

Zaakceptowano: 18 marca 2016

Accepted: 18 March 2016

\section{Sugerowana cytacja/Suggested citation:}

Tokarski, A., Matuszak, M. (2016). Upadłość jako instytucja gospodarki rynkowej, Przedsiębiorczość - Edukacja, 12, 199-216.

Wstęp

Upadłość to jedna z najważniejszych instytucji gospodarki rynkowej. W związku z burzliwymi przemianami, których obecnie doświadcza globalna gospodarka, co nie pozostaje bez wpływu na gospodarki narodowe i regionalne, waga problematyki bankructw i upadłości staje się trudna do przecenienia (Morawska, 2013a). Właściwe regulacje prawne oraz odpowiednie otoczenie instytucjonalne działalności gospodarczej, również w zakresie procesów upadłościowych przedsiębiorstw, wywierają pozytywny wpływ na wzrost gospodarczy oraz rozwój państw i społeczeństw (Lee i in., 2011; Morawska, 2011). Dzieje się tak dlatego, że instytucja upadłości, jeśli jest skonstruowana prawidłowo, tzn. adekwatnie do sytuacji istniejącej w danej przestrzeni gospodarczej, zapewnia zarówno efektywną alokację środków produkcji, jak i skuteczną ochronę wierzycieli (Bauer, 2009).

Celowość stałego monitorowania zakresu i przyczyn upadłości przedsiębiorstw w danej gospodarce, jak również w coraz większym stopniu gospodarstw domowych (czyli upadłości konsumenckiej) wynika przede wszystkim z faktu, że sprawny przebieg tych procesów stanowi nieodłączny element efektywnie działającej gospodarki rynkowej. Nieprzypadkowo zatem sformułowane zostało stwierdzenie, iż kapitalizm, w którym nie zdarzają się bankructwa i upadłości, jest jak chrześcijaństwo bez piekła. Stwierdzenie to odnosi się obecnie w coraz większym stopniu również do państw (Adamska, Mączyńska, 2013).

Celem artykułu jest określenie pojęcia i elementów upadłości jako instytucji w warunkach polskiej gospodarki rynkowej na podstawie obowiązujących w tym zakresie do $2015 \mathrm{r}$. regulacji prawnych. Podstawowe metody, które zostały wykorzystane w trakcie pisania artykułu, to analiza danych zastanych, czyli obowiązujących przepisów prawa dotyczących upadłości przedsiębiorstw w Polsce, oraz analiza literatury przedmiotu dotyczącej upadłości jako instytucji funkcjonującej w warunkach gospodarki rynkowej z uwzględnieniem gospodarki polskiej. 
Pojęcie i znaczenie instytucji

Pojęcie instytucji jest wieloznaczne. Stosowane jest w różnych obszarach wiedzy i nadaje się mu różne znaczenia (North, 1991; Gaweł, Klimczak, 2005). To jedno z fundamentalnych pojęć związanych z tzw. nową ekonomią instytucjonalną. Zdaniem D. Northa, jednego z najbardziej prominentnych przedstawicieli tego nurtu, instytucje stanowią wykształcone w obrębie społeczeństw reguły (przymusy), według których przebiegają złożone interakcje społeczne, polityczne i ekonomiczne. Dzięki nim następuje zmniejszanie poziomu niepewności i wysokości kosztów działań podejmowanych przez ludzi, co sprzyja wzrostowi skłonności do podejmowania tych działań, w tym gospodarczych, oraz wzrostowi ich efektywności. Z uwagi na różnice w sposobie i sile ich oddziaływania wyróżnia się instytucje nieformalne i formalne oraz system „wzmocnień”, który stoi na straży przestrzegania obowiązujących reguł. Reguły bądź przymusy nieformalne to dominujące w danej przestrzeni ekonomicznej zwyczaje, tradycje, normy czy kodeksy zachowań. Mają one charakter pierwotny wobec reguł bądź przymusów formalnych, które określone są przez system obowiązujących w danej przestrzeni gospodarczej praw. System wzmocnień określa sposoby narzucania i egzekwowania obowiązujących (dominujących) reguł formalnych i nieformalnych, na których straży stoi państwo i jego system prawny. Skuteczność systemu wzmocnień zależy zarówno od charakteru instytucji formalnych, jak i od stopnia rozbudowy infrastruktury niezbędnej do wymuszania obowiązujących reguł postępowania.

$\mathrm{Na}$ instytucję upadłości składają się zatem regulacje prawne określające obowiązujące procedury upadłościowe, zakorzenione w społeczeństwie przekonania i stosunek do zjawiska upadłości ${ }^{1}$, jak również cały aparat zapewniający osiąganie celów postępowań upadłościowych, który tworzą sędziowie orzekający w sprawach upadłościowych, syndycy zarządzający masą upadłości, nadzorcy sądowi, zarządcy itp., a także wysokość czy/i nieuchronność sankcji za łamanie obowiązujących praw w zakresie procedur upadłościowych i związany z tym cały system penitencjarny.

\section{Modele instytucji upadłości w gospodarkach rynkowych}

Potrzeba istnienia instytucji upadłości w gospodarce rynkowej nie budzi wątpliwości. J. Stiglitz, podobnie jak wielu innych autorów, zalicza upadłość do podstawowych instytucji gospodarki rynkowej, która powinna gwarantować poszanowanie praw wierzycieli i efektywną alokację środków produkcji (Stiglitz, 2005). Istotny problem stanowi jednak określenie i wybór odpowiedniego modelu upadłości, który w możliwie największym stopniu zapewniałby realizację tych dwóch zasadniczych postulatów.

W toku rozwoju prawa upadłościowego wykształciły się trzy podstawowe modele postępowania z niewypłacalnym dłużnikiem (II szansa, 2011):

Model A - likwidacyjny, historycznie najstarszy, w myśl którego przedsiębiorstwo niewypłacalnego dłużnika powinno zostać zlikwidowane, a jego majątek rozdzielony pomiędzy wierzycieli. To postępowanie nazywane jest egzekucją generalną, a jej podstawową funkcją jest

\footnotetext{
${ }^{1} \mathrm{Na}$ przykład w Japonii upadłość przedsiębiorcy postrzegana jest jako „utrata twarzy”, podczas gdy w USA i w wielu krajach Europy Zachodniej traktowana bywa jako zwykły element gry rynkowej. Warto w tym miejscu wskazać, że według J. Northa oddziaływanie instytucji nieformalnych na zachowania ludzi jest bardzo silne, zdecydowanie silniejsze, niż się powszechnie sądzi.
} 
uporządkowanie wzajemnych stosunków wierzycieli przy podziale majątku dłużnika. W modelu tym zakłada się wyodrębnianie upadłości o podłożu kryminalnym, tzn. celowych, od upadłości likwidacyjnych, będących wynikiem rzeczywiście nieefektywnych działań gospodarczych przedsiębiorcy.

Model B - układowy, wykształcił się w toku ewolucji prawa upadłościowego, gdy okazało się, że nie zawsze likwidacja majątku dłużnika jest najkorzystniejsza dla wierzycieli. Polega on na zapewnieniu warunków do zawarcia „układu” pomiędzy wierzycielami a dłużnikiem, w którym ci pierwsi ograniczą swoje roszczenia, aby umożliwić kontynuację działania przedsiębiorstwa dłużnika, co pozwalałoby na zaspokojenie ich roszczeń w sposób „wyższy” niż w przypadku likwidacji przedsiębiorstwa dłużnika. „Układ” przyjmowany jest większością "głosów” wierzycieli i obowiązuje wtedy wszystkich, czyli również tych wierzycieli, którzy nie głosowali za jego przyjęciem. W modelu tym koszt „odrodzenia” przedsiębiorstwa dłużnika spoczywa na wierzycielach, których roszczenia zaspokajane są w stopniu wyższym niż w przypadku upadłości likwidacyjnej.

Model C - ochronny, stosowany w celu czasowego zawieszenia praw wierzycieli do egzekwowania roszczeń, aby umożliwić dłużnikowi dokonanie restrukturyzacji własnego, nieefektywnego przedsiębiorstwa. Model ten jest popularny w USA, a od odpowiedniej części obowiązującej tam ustawy upadłościowej często określa się go jako Chapter 11.

Opisane powyżej bardzo ogólne modele mają charakter teoretyczny i porządkujący. W praktyce występujące w poszczególnych krajach szczegółowe procedury upadłości zawierają elementy należące do wszystkich trzech modeli. O przyporządkowaniu konkretnego rozwiązania do danego modelu decyduje generalne nastawienie ustawodawcy w odniesieniu do celów, jakie ma spełniać prawo upadłościowe. W tym sensie wyróżnić można dwa generalne modele prawa upadłościowego (Morawska, 2011):

- prolikwidacyjny,

- proukładowy.

Innym podziałem modeli upadłościowych jest podział oparty na zakresie praw przyznawanych w procesie upadłościowym dłużnikom i wierzycielom. Wyróżnia się tu modele (Mączyńska, Morawska, 2015):

- przyjazne wierzycielom (ang. pro creditor lub debt-friendly),

- przyjazne dłużnikom (ang. pro-debtor lub equity-friendly),

- mieszane (hybrydowy).

W modelu przyjaznym dłużnikom najczęściej stosowanym sposobem zaspokajania wierzycieli przez upadłego jest wybór opcji restrukturyzacyjnej, a nie likwidacyjnej przedsiębiorstwa dłużnika. Systemom tym często zarzuca się, że wierzyciele traktowani są w nich gorzej niż dłużnicy oraz, że osoby zarządzające niewypłacalną jednostką pozostawiane są u władzy częściej niż w systemach przyjaznych wierzycielom. Rozwiązanie takie uzasadnia jednak założenie, że „starzy” menedżerowie znają problemy niewypłacalnej firmy lepiej niż ewentualni „nowi” zarządcy i właśnie dlatego należałoby umożliwiać im dalsze pełnienie funkcji zarządczych. W modelu tym akcentuje się również aspekty społeczne, nawiązujące do możliwości zachowywania miejsc pracy w niewypłacalnych podmiotach.

W modelu promujący ochronę interesów wierzycieli preferowane jest usuwanie z zarządu przedsiębiorstwa dotychczasowych menedżerów, których obarcza się odpowiedzialnością za zły stan finansowy przedsiębiorstwa. W modelu tym przyjmuje się, że reorganizacje niewypłacalnego podmiotu przynoszą zazwyczaj znikome efekty. Zauważa się również, iż często, po wielu nieudanych próbach restrukturyzacji, przedsiębiorstwo i tak jest likwidowane, co 
znacznie wydłuża czas jego „agonii” i generuje wysokie koszty tych działań. Ponadto w modelu tym powstają sprzyjające warunki do powstawania tzw. grup uprzywilejowanych wierzytelności, co związane jest z tym, że jedni wierzyciele zyskują lepszą pozycję przy podziale wierzytelności niż inni.

Obecnie w świecie dominuje model hybrydowy, przy czym można wyróżnić kraje o modelach bardziej lub mniej zbliżonych do jednego z wyżej opisanych. Do krajów o modelu uprzywilejowującym wierzycieli R. Bliss zalicza: Wielką Brytanię, Niemcy, Włochy, Chiny, Japonię oraz państwa skupione w ramach Brytyjskiej Wspólnoty Narodów, a wśród krajów uprzywilejowujących dłużnika wymienia: Hiszpanię, wiele krajów Ameryki Łacińskiej, Bliskiego Wschodu oraz Afryki. Do państw o modelu hybrydowym należą zaś jego zdaniem: USA, Kanada i Francja (Bliss, 2003).

Model instytucji upadłości, a przede wszystkim jego funkcje - powinny być dostosowane do poziomu rozwoju instytucjonalnego kraju, odpowiadać potrzebom społeczno-gospodarczym oraz powszechnie przyjętym w obrocie gospodarczym zwyczajom. Spełnienie tych warunków zapewnia wysoką jakość instytucji upadłości, co wyraża się w społecznie pożądanych zachowaniach podmiotów gospodarczych. Ich niespełnienie prowadzi zazwyczaj do rozwoju instytucji upadłości powodujących patologiczne konsekwencje w sferze działań gospodarczych i społecznych, np. „bezkarne” występowanie tzw. upadłości reżyserowanych, bardzo niski czy niesprawiedliwy stopień zaspokajania wierzycieli, możliwość ukrywania przez dłużnika majątku.

\section{Infrastruktura upadłości jako istotny element instytucji upadłości}

Dla prawidłowego funkcjonowania i rozwoju przedsiębiorstw niezbędna jest instytucjonalna infrastruktura działalności gospodarczej, w tym także infrastruktura upadłości. O niezbędności dobrze działającej infrastruktury przekonują ujawniające się globalne i regionalne dysfunkcje gospodarki wynikające z mniej lub bardziej spektakularnych upadłości wielkich przedsiębiorstw, które pociągają dyfuzję zagrożeń dla innych przedsiębiorstw z efektem domina upadłości włącznie (Mączyńska, 2015a).

Infrastruktura upadłości stanowi jeden z najważniejszych elementów instytucji upadłości. Powinna ona zapewniać skuteczną realizację takich funkcji, jak: sprawne wykrywanie zagrożeń upadłością, sprawny przebieg procesów upadłościowych szybko i skutecznie oczyszczających rynek z nieefektywnych podmiotów gospodarczych, które stwarzają zagrożenia dla płynności obrotu (funkcja profilaktyczna i regulatora gospodarki wolnorynkowej), skuteczne karanie dłużników niezgłaszających lub zbyt późno zgłaszających wniosek o ogłoszenie upadłości (funkcja prewencyjna), możliwość szybkiej i „łatwej” restrukturyzacji przedsiębiorstw przeżywających jedynie przejściowe trudności finansowe czy ułatwienie im powrotu do prowadzenia normalnej działalności gospodarczej (Prusak, 2012). Znaczenie właściwej infrastruktury upadłości wynika również z niezwykłej złożoności zjawiska upadłości przedsiębiorstw i krzyżowania się $\mathrm{w}$ tym procesie różnych, często przeciwstawnych interesów stron $\mathrm{w}$ nim uczestniczących. Instytucjonalną infrastrukturę upadłości E. Mączyńska definiuje jako „całokształt warunków jurysdykcyjno-organizacyjnych, obejmujących zarazem system regulacji prawnych, jak i instytucji, które bezpośrednio lub pośrednio są angażowane w sytuacjach, gdy dochodzi do upadłości przedsiębiorstwa lub zagrożenia nią" (Mączyńska, 2012).

Instytucje stanowiące elementy infrastruktury związanej z procesami upadłości przedsiębiorstw mogą mieć różny charakter oraz charakteryzować się różnym poziomem rozwoju 
i jakości pracy, co przekłada się na racjonalność przebiegu procesu upadłości. Do instytucji stanowiących infrastrukturę upadłości zaliczyć można, oprócz jednostek sądu gospodarczego jako takich, prowadzących proces upadłości „bezpośrednio”, szereg instytucji o charakterze komercyjnym i niekomercyjnym, które świadczą różnorodne usługi pomocnicze, związane np. z dokonywaniem wycen, analiz zagrożenia upadłością czy weryfikacją dokumentacji finansowo-księgowej. Zaliczyć do nich można również: urzędy statystyczne, wywiadownie gospodarcze, instytucje ratingowe, biura informacji gospodarczej, firmy doradcze, placówki edukacyjne, komorników itp.

Instytucjonalna infrastruktura upadłości obejmuje zatem wszystkie materialne i niematerialne elementy niezbędne do wykonywania obowiązującego prawa upadłościowego, tzn. systemy organizacyjne i reguły działania, które mają wpływ na procedury i konsekwencje upadłości dla wszystkich zainteresowanych tym procesem stron, czyli interesariuszy procesu upadłości.

\section{Upadłość jako instytucja ekonomiczna i prawna}

Upadłość jako instytucja rozpatrywana może być w dwojakim znaczeniu - ekonomicznym i prawnym. Celem upadłości jako instytucji ekonomicznej, jak wspomniano o tym już wyżej, jest przenoszenie zasobów z miejsc o niedostatecznej efektywności ich wykorzystania do miejsc o wyższej efektywności ich wykorzystania. Następuje to przez upadki jednych, a także powstawanie i rozwój innych przedsiębiorstw, do których trafiają zasoby niedostatecznie efektywnie wykorzystywane. Procesy te przyczyniają się do wzrostu gospodarczego i zwiększania poziomu dobrobytu, są zatem niezwykle korzystne z punktu widzenia całego społeczeństwa.

Zgodnie z zadeklarowanym w polskim prawie upadłościowym celem instytucji upadłości jest (Tokarski, 2015):

- zaspokojenie wierzycieli niewypłacalnego dłużnika (funkcja windykacyjna),

- niedopuszczenie do dalszych niewypłacalności, które są następstwem niepłacenia zobowiązań przez niewypłacalnego dłużnika (funkcja profilaktyczna),

- kształcenie wśród przedsiębiorców określonych wzorów zachowań, które można określić jako postawę rzetelnego przedsiębiorcy (funkcja wychowawcza),

- w ograniczonym stopniu - funkcja oddłużeniowa.

Polski ustawodawca zdecydował także, że rozstrzyganie konfliktu interesów pomiędzy dłużnikiem i jego wierzycielami na tle niewypłacalności następuje w jednym postępowaniu sądowym.

Upadłość w znaczeniu instytucji prawnej należy rozpatrywać jako ogół przepisów prawa definiujących kryteria określania upadłości², regulujących tryb postępowania upadłościowego i działania infrastruktury upadłości. Stanowi je prawo upadłościowe, czyli te obszary/gałęzie prawa, które regulują stosunki i skutki niewypłacalnego przedsiębiorcy z jego wierzycielami (i innymi interesariuszami), oraz procedury, które umożliwiają wierzycielom zaspokojenie ich roszczeń na skutek likwidacji majątku upadłego albo przez zawarcie układu wierzycieli z upadłym (Zedler, 2009).

${ }^{2}$ Kryteria określania upadłości stanowią z jednej strony zagadnienie o kluczowym znaczeniu, z drugiej zaś strony istnieje wiele obiektywnych przesłanek powodujących, że ustalenie tych kryteriów w sposób jednoznaczny jest niezwykle trudne, czy wręcz niemożliwe. Prawo określa precyzyjnie stany ekonomiczne kwalifikujące przedsiębiorstwo jako upadłe, jednak zastosowanie tych obowiązujących reguł z praktycznego punktu widzenia w wielu przypadkach okazuje się niezwykle trudne. Należy też wspomnieć, że problemowi temu poświęcona jest obszerna literatura. 
Jednym z zasadniczych celów upadłości jako instytucji prawnej jest dążenie do sprawiedliwego zaspokojenia wszystkich wierzycieli z majątku trwale niewypłacalnego dłużnika (czyli upadłego) lub, w pewnych sytuacjach, zapewnienie warunków sprzyjających „odrodzeniu się" upadłego przedsiębiorstwa. Upadłość, podobnie jak egzekucja sądowa w sprawach cywilnych, służy urzeczywistnieniu norm materialnego prawa cywilnego w zakresie stosunków zobowiązaniowych (Lewandowski, Wołowski, 2014). Według K. Flagi-Gieruszyńskiej prawna instytucja upadłości polega na odebraniu bądź ograniczeniu prawa dłużnika do korzystania ze swojego majątku oraz na rozporządzaniu nim w celu równomiernego zaspokojenia wierzycieli (Flaga-Gieruszyńska, 2012). Należy zauważyć, że charakter regulacji prawnych determinuje ekonomiczne i społeczne skutki upadłości.

W Polsce prawo upadłościowe przenika różne gałęzie prawa, szczególnie te odnoszące się do zasad prowadzenia działalności gospodarczej i dziedzin, z którymi w ramach tej działalności przedsiębiorcy mają kontakt. Podstawowym aktem normatywnym regulującym kwestie związane z upadłością jest ustawa Prawo upadłościowe i naprawcze. Należy wspomnieć, że od 1 stycznia 2016 r. nastąpiła istotna zmiana - kwestie upadłości likwidacyjnej reguluje Prawo upadłościowe (Dz.U. z 2015 r., poz. 233), a kwestie postępowań układowych i naprawczych Prawo restrukturyzacyjne (Dz.U. z 2015 r., poz. 978). Powodem tej zmiany jest dążenie do dostosowania obowiązującego prawa do warunków działania przedsiębiorstw w nowoczesnych gospodarkach, jak również do wyeliminowania w możliwie największym stopniu słabości i dysfunkcji prawa obowiązującego dotychczas. Zagadnienia związane z upadłością regulowane są obecnie przez szereg innych ustaw lub cząstkowych zapisów w tych ustawach oraz aktami niższej rangi, których w sumie jest ok. 30. Fakt takiego rozproszenia regulacji prawnych oceniać można krytycznie, gdyż utrudnia to ich stosowanie.

Polskie prawo powinno być zharmonizowane z prawem europejskim. Do podstawowych regulacji unijnych należą:

1. Rozporzadzenie Rady (WE) Nr 1346/2000 z 29.5.2000 r. w sprawie postepowania upadłościowego (Dz.U. WE L nr 160, s. 1);

2. Dyrektywa Parlamentu Europejskiego i Rady 2001/17/WE z 19.3.2001 r. w sprawie reorganizacji i likwidacji zakładów ubezpieczeń (Dz.U. WE L nr 110, s. 28 - obowiązywała do 31.12.2015 r.);

3. Dyrektywa Parlamentu Europejskiego i Rady 2001/24/WE z 4.4.2001 r. w sprawie reorganizacji i likwidacji instytucji kredytowych (Dz.U. WE L nr 125).

4. W obecnym stanie prawnym postępowanie upadłościowe może przybierać dwie formy (Podel, Olszewska, 2012):

- postępowanie mające na celu likwidację majątku upadłego,

- postępowanie z możliwością zawarcia układu.

W obu przypadkach podstawą rozpoczęcia postępowania upadłościowego jest trwałe zaprzestanie regulowania przez przedsiębiorstwo swych zobowiązań bądź przekroczenie określonej przepisami prawa relacji pomiędzy zobowiązaniami i majątkiem dłużnika. Jakkolwiek przepisy prawa regulują te kwestie bardzo precyzyjnie, to praktyczne stosowanie tych przepisów nastręcza wiele trudności (Collins, 2015)3․ Do najważniejszych zaliczyć można m.in. ustalenie momentu określenia upadłości w kontekście problemów związanych z szacunkami i wycenami majątku przedsiębiorstwa, oceną perspektyw działania firmy czy kwestią

${ }^{3} \mathrm{~J}$. Collins, podobnie jak wielu innych autorów, formułuje tezę, że ekonomiczny stan upadłości przedsiębiorstwa pojawia się w zasadzie najczęściej dużo wcześniej niż upadłość w sensie prawnym. Szerzej zob. np. Collins (2015). 
dotrzymywania przez kontrahentów warunków umów . Od 2016 r., gdy obowiązywać zaczną nowe regulacje, podjęcie postępowania restrukturyzacyjnego chroniącego przedsiębiorstwo przed upadłością, będzie mogło być rozpoczynane wskutek swobodnej oceny przedsiębiorcy co do możliwości zajścia zagrożenia jego przedsiębiorstwa upadłością. Mimo że trudno jest obecnie oceniać przyszłe zainteresowanie przedsiębiorców tą formą przeciwstawiania się antycypowanym trudnościom, to niewątpliwie, bynajmniej z teoretycznego punktu widzenia, wydaje się, że rozwiązanie to posiada wiele zalet.

Zgodnie z art. 2 Prawa restrukturyzacyjnego, które weszło w życie od 2016 r. (Ustawa z dnia 15 maja 2015 r. Prawo restrukturyzacyjne, Dz.U. z 2015 r., poz. 978), przewiduje się cztery rodzaje działań restrukturyzacyjnych:

1. postępowanie o zatwierdzenie układu,

2. przyspieszone postępowanie układowe,

3. postępowanie układowe,

4. postępowanie sanacyjne.

Upadłość likwidacyjną sąd ogłasza wówczas, gdy dłużnik nie jest w stanie regulować swych zobowiązań lub suma zobowiązań przekracza majątek dłużnika oraz brak jest podstaw do ogłoszenia upadłości układowej. Ogłoszenie upadłości następuje jednak pod warunkiem, że majątek dłużnika wystarczy na pokrycie kosztów upadłości Zarząd nad majątkiem upadłego obejmuje syndyk, którego zadaniem jest wyprzedaż majątku upadłego w celu spłacenia wierzycieli z uzyskanych w ten sposób kwot (Gurgul, 2010). Upadłość likwidacyjna prowadzi zasadniczo do zaprzestania działalności gospodarczej upadłego (Łodzianna, Makuch, 2005), a spłata wierzytelności następuje wskutek wyprzedaży majątku dłużnika. W momencie ogłoszenia upadłości uruchamiane są procedury ochrony majątku dłużnika mające na celu ochronę interesów wierzycieli. Najkorzystniejszym rozwiązaniem jest sprzedaż przedsiębiorstwa upadłego w całości (przedsiębiorstwa w ruchu), sprzedaż zorganizowanej części przedsiębiorstwa, a w ostateczności poszczególnych składników majątku. Postępowanie upadłościowe nadzoruje sędzia, zwany sędzią komisarzem, który do przeprowadzenia procedury upadłościowej, tzn. do sprzedaży majątku upadłego w celu jak najwyższego zaspokojenia wierzycieli, wyznacza syndyka. Pierwszym zadaniem syndyka po objęciu majątku upadłego jest sporządzenie spisu inwentarza, oszacowanie masy upadłości oraz sporządzenie planu likwidacyjnego określającego sposoby i terminy sprzedaży mienia, szacunkowy czas trwania postępowania, preliminarz kosztów likwidacji przedsiębiorstwa oraz ewentualne uzasadnienie prowadzenia działalności gospodarczej w przedsiębiorstwie upadłego. Syndyk sporządza listę wierzytelności, badając zasadność roszczeń i kontrolując płatności dokonywane w przeciągu półrocznego okresu czasu poprzedzającego ogłoszenie upadłości. Roszczenia wierzycieli są dzielone na kategorie, które zaspokajane są w określonej kolejności. Po zatwierdzeniu planów podziału następuje faktyczna likwidacja majątku, czyli jego sprzedaż $\mathrm{w}$ drodze przetargu lub $\mathrm{z}$ wolnej ręki. Po spieniężeniu masy upadłości następuje podział uzyskanych funduszy, jednorazowo lub kilkukrotnie w miarę postępów w sprzedaży. Całkowite zlikwidowanie masy upadłości kończy postępowanie upadłościowe.

Upadłość układową sąd ogłasza wtedy, gdy istnieją racjonalne przesłanki na uratowanie firmy oraz gdy zostanie uprawdopodobnione, że w drodze układu wierzyciele zostaną zaspokojeni w stopniu wyższym, niż zostaliby zaspokojeni po przeprowadzeniu postępowania upadłościowego obejmującego likwidację majątku dłużnika (Tokarski A., Tokarski M., 2014).

\footnotetext{
${ }^{4}$ Ostatnia z wymienionych kwestii rozpatrywana może być w ramach tzw. kontraktualnej teorii firmy.
} 
Celem upadłości układowej jest zatem zaspokojenie wierzycieli uprawdopodobnionymi przyszłymi zyskami przedsiębiorstwa. Oznacza to dalsze funkcjonowanie podmiotu i uczestnictwo w obrocie gospodarczym oraz utrzymanie zatrudnienia. Warunkiem koniecznym ogłoszenia upadłości z możliwością zawarcia układu jest przedstawienie realnych propozycji układowych zapewniających spłatę zobowiązań dłużnika w wysokości nie niższej niż w przypadku likwidacji jego majątku. Propozycje układowe przedstawia dłużnik i uzasadnia je dołączoną do nich analizą sytuacji majątkowo-finansowej przedsiębiorstwa, jego pozycji konkurencyjnej, przewidywaniami dotyczącymi sytuacji rynku, na którym działa jednostka, oraz analizą struktury ryzyka. Zasadniczym elementem propozycji układowych jest sposób restrukturyzacji zadłużenia przedsiębiorstwa, który może obejmować zmniejszenie sumy zobowiązań, rozłożenie ich na raty, odłożenie w czasie terminu spłaty, konwersję wierzytelności na udziały i akcje (Ustawa z dnia 28 lutego 2003 r. Prawo upadłościowe i naprawcze, Dz.U. z 2009 r. nr 175, poz. 1361, art. 270). Układ, po przyjęciu go przez zgromadzenie wierzycieli, jest zatwierdzany przez sędziego komisarza. Przedsiębiorstwo upadłego jest zarządzane przez jego dotychczasowy zarząd pod nadzorem powołanego nadzorcy sądowego lub, w sytuacji odwołania dotychczasowego kierownictwa, przez zarządcę. Po wydaniu postanowienia o zawarciu układu i jego realizacji, czyli spłacie zobowiązań zgodnie z przyjętym harmonogramem, sąd wydaje postanowienie o wykonaniu układu, który stanowi podstawę wykreślenia z ksiąg wieczystych i rejestrów wpisów dotyczących upadłości. Jeżeli układ nie jest realizowany, sędzia może zdecydować o zamianie trybu postępowania na upadłość likwidacyjną (Świeboda, 2003).

\section{Podmioty zaangażowane w proces postępowania upadłościowego przedsiębiorstw - główni interesariusze i obszary ich zainteresowań}

W postępowaniu upadłościowym bierze udział zazwyczaj wielu uczestników, którzy mają różne, często sprzeczne ze sobą motywy postępowania („interesy”). Podstawowym podziałem podmiotów postępowania upadłościowego jest ich podział na organy oraz uczestników postępowania. Do organów postępowania upadłościowego zalicza się organy sądowe w postaci sądu i sędziego komisarza oraz organy pozasądowe, którymi są: syndyk, nadzorca sądowy i zarządca (Marszałkowska-Krześ, Gil, 2011).

Uczestnikami postępowania upadłościowego są: dłużnik, czyli podmiot, wobec którego wydano postanowienie o ogłoszenie upadłości, oraz wierzyciele, czyli każdy podmiot uprawniony do zaspokojenia z masy upadłości swych wierzytelności, choćby wierzytelności takie nie wymagały zgłoszenia.

W postępowaniu upadłościowym biorą również zazwyczaj udział tzw. podmioty incydentalne, tj.: biegli sądowi, komornicy sądowi, notariusze, oraz podmioty służące syndykowi pomocą, do których zalicza się zatrudnianych przez niego księgowych, rzeczoznawców, personel biurowy, ochronę itp.

Wymienione powyżej podmioty związane są z postępowaniem upadłościowym w sposób bezpośredni. Postępowanie upadłościowe dotyczy jednak jeszcze innych „zainteresowanych”. Dla przedstawienia ogółu mniej lub bardziej powiązanych z procesem upadłościowym „stron” wprowadzić można poniższy podział.

Charakter prowadzonego postępowania upadłościowego różnicuje w pewnej mierze rolę i „interesy” głównych aktorów postępowania upadłościowego. W przypadku postępowania upadłościowego głównym „aktorem” jest sąd, sędzia komisarz i syndyk, którego głównym 
i jedynym w zasadzie zadaniem jest jak najszybsze spieniężenie majątku i zaspokojenia wierzycieli (Wardzińska, 2013). Cała procedura upadłości odbywa się pod nadzorem sędziego komisarza, który sprawuje nadzór nad legalnością i racjonalnością postępowania syndyka sprawującego zarząd nad upadłym przedsiębiorstwem. W przypadku upadłości z możliwością zawarcia układu, jakkolwiek czynności kontrolne nad legalnością i racjonalnością postępowania nadal sprawuje sędzia komisarz i nadzorca sądowy, to bieżący zarząd sprawowany może być (choć nie musi) przez dotychczasowe organy przedsiębiorstwa, a propozycje co do sposobu restrukturyzacji zadłużenia mogą zależeć w dużej mierze od wierzycieli. Z racji odmienności zasadniczych celów postępowania w obu przypadkach odmiennie kształtują się motywy i podstawowe cele działania („interesy”) głównych „aktorów” procesu upadłościowego.

W przypadku postępowania likwidacyjnego, jeśli chodzi o działanie sądu, dominujące znaczenie ma nadzór nad legalnością podejmowanych w trakcie likwidacji działań, podczas gdy w przypadku postępowania upadłościowego niepomiernie wzrasta znaczenie sądu jako organu kontrolującego racjonalność ekonomiczną i sprawiedliwość toczących się procedur 5 . Wyrazem tego jest istnienie instytucji, tzw. rady wierzycieli, która może wpływać na kształt zawieranego układu.

Jak wspomniano powyżej, upadłość podmiotu gospodarczego jest zdarzeniem, które pociąga za sobą wiele różnorakich konsekwencji i kosztów dla znacznej grupy osób i instytucji powiązanych w różny sposób z upadłym przedsiębiorstwem. Ich postawy i zachowania w procesie upadłości kształtowane są przez dostrzegane przez nich „interesy”, tzn. postrzegane korzyści i zagrożenia związane $\mathrm{z}$ charakterem prowadzonego postępowania.

Modelowy układ „interesów” głównych „aktorów” postępowania opisać można ogólnie w sposób następujący (Morawska, Roszkowska, 2011; Tokarski A., Tokarski M., 2013):

Właściciele dążą najczęściej do utrzymania działalności zadłużonej jednostki i odzyskania jak największej kwoty środków pieniężnych zainwestowanych w przedsiębiorstwo ${ }^{6}$. W hierarchii podmiotów uprawnionych do podziału masy upadłościowej zajmują jednak ostatnie miejsce. W praktyce, jak pokazują to wyniki licznych badań, w przypadku typowej procedury likwidacyjnej, rzadko udaje im się odzyskać choćby część zainwestowanego kapitału. Sytuacja ta rodzi zatem naturalne zainteresowanie wspomnianą $\mathrm{w}$ przypisie minimalizacją strat przez formalne i nieformalne działania w okresie poprzedzającym upadłość w celu ukrycia faktycznego majątku przez zmiany form prawnych czy tworzenie nowych podmiotów i transferowanie do nich majątku. Są to działania naruszające w istotny sposób interesy wierzycieli i względnie trudno kontrolowalne przez sąd w trakcie postępowania upadłościowego.

Menedżerowie upadłego przedsiębiorstwa $\mathrm{z}$ racji pełnionej funkcji posiadają oni najpełniejszą wiedzę o faktycznym stanie upadającego przedsiębiorstwa. Motywem ich działania w okresie poprzedzającym upadłość lub gdy uczestniczą w procesie upadłościowym, jest uzyskiwanie możliwie najwyższego wynagrodzenia. Uwzględniając swoją sytuację i rozważając

\footnotetext{
${ }^{5}$ Chodzi głównie o kontrolowanie sprawiedliwego rozdziału kosztów i korzyści dla różnych grup wierzycieli wynikających z realizowanego układu pomiędzy upadłym a wierzycielami.

${ }^{6}$ Rodzić to może skłonność do podejmowania mniej lub bardziej legalnych działań mających na celu ochronę własnego majątku, takich jak jego przemieszczanie do innych podmiotów, zbywanie na rzecz rodziny itp. Działania te mogą być podejmowane zarówno w trakcie samego procesu upadłościowego, co jednak z racji nadzoru organów sądowych jest znacznie utrudnione lub wręcz niemożliwe, jak i, przede wszystkim, w okresie przed „otwarciem” postępowania upadłościowego. W związku z powyższym w celu zapobiegania takim praktykom upadły musi przedstawiać sądowi zakres swych działań finansowych dokonywanych w ciągu sześciu miesięcy poprzedzających upadłość. Przedmiotem dyskusji można uczynić to, czy jest to okres „wystarczająco” długi. Jest to szczególnie istotne w przypadku, wcale nierzadkich w warunkach polskich, tzw. upadłości reżyserowanych.
} 
skutki dla przedsiębiorstwa, mają oni, w pewnych granicach, możliwości wpływania na ocenę zasadności i moment złożenia wniosku o wszczęcie postępowania upadłościowego, biorąc w swych kalkulacjach pod uwagę możliwe skutki, w tym sankcje finansowe i karne, jak również wynikające z ich decyzji skutki dla przedsiębiorstwa, określone „głębokością” zapaści finansowej i ewentualnymi szansami prowadzenia postępowania układowego ${ }^{7}$. Formalnym ich obowiązkiem jest przeciwdziałanie upadłości przedsiębiorstwa, co związane jest $\mathrm{z}$ utrzymaniem stanowiska pracy, prestiżem w środowisku zawodowym czy realizacją własnych ambicji. Na gruncie zdecydowanie bardziej realistycznych założeń behawioralnych, formułowanych w ramach tzw. nowej ekonomii instytucjonalnej, przyjmować jednak należy, że równie powszechnymi typami zachowań są różne odmiany oportunizmu, co skutkuje tym, że partykularne interesy menedżera stają się nadrzędne wobec interesów przedsiębiorstwa i właścicieli ${ }^{8}$.

Administratorzy postępowań upadłościowych, tzn. syndycy, nadzorcy, zarządcy, działając $\mathrm{w}$ ramach względnie rygorystycznych przepisów prawa i pod nadzorem sądu, również jako „agenci” ", zainteresowani są maksymalizowaniem swych wynagrodzeń. Utrzymując założenie o oportunistycznej naturze ludzkich zachowań, cel ten, podobnie jak w przypadku działań menedżera, może być względnie łatwo realizowany ${ }^{10}$. Z racji ich usytuowania i charakteru wykonywanych w procesie upadłościowym zadań (spełniają w praktyce funkcje zarządcze/menedżerskie) administratorzy postępowań upadłościowych mają wręcz decydujący wpływ na przebieg i efektywność postępowania upadłościowego. Sprawność przebiegu postępowania upadłościowego, mierzona np. czasem jego trwania, kosztem prowadzonych działań (na które znaczący wpływ może wywierać wynagrodzenie syndyka) czy skutecznością zaspokojenia wierzycieli determinowana jest istnieniem dobrego i sprawnie działającego systemu motywacji łączącego materialne efekty pracy tej grupy interesariuszy z efektywnością postępowań upadłościowych ${ }^{11}$.

Kredytodawcy, pożyczkodawcy oraz inwestorzy są zainteresowani bezpieczeństwem i pewnością zwrotu zainwestowanych środków. W zależności od oceny sytuacji upadającego przedsiębiorstwa zainteresowani mogą być działaniami na rzecz „wzmocnienia” i polepszenia sytuacji finansowej upadającego przedsiębiorstwa lub możliwie najszybszym i pełnym odzyskaniem zainwestowanych środków. W fazie postępowania upadłościowego jest to w zasadzie dominujący i jedyny motyw ich działania. Należy zauważyć, że często właśnie oni, jako pierwsi, składają wnioski o upadłość dłużnika, kierując się interesem własnym, w małym zaś stopniu interesem upadłego. Pozytywną stroną takiego stanowiska jest uruchamianie i podtrzymywanie działania ściśle ekonomicznego mechanizmu weryfikacji upadłego.

Dostawcy i odbiorcy poprzez wczesną identyfikację kłopotów finansowych swojego kontrahenta mogą podjąć decyzję, czy dalsza współpraca z nim ma sens, gdyż z punktu widzenia dostawcy może on nie zapłacić za zakupione materiały lub z punktu widzenia odbiorcy może nie dostarczyć zamówionych produktów. Kłopoty upadającego mogą przenieść się na kondycję finansową dostawców i odbiorców. Gdy zorientują się oni, że kontrahent nie jest wiarygodny, mogą zacząć szukać dla siebie innych odbiorców swoich produktów (dostawcy) lub innych dostawców (odbiorcy). Realne możliwości zamiany dostawców/odbiorców zależą jednak od

\footnotetext{
${ }^{7}$ Podobne kwestie analizowane są np. w teorii agencji.

${ }^{8}$ Wskazuje to na znaczenie organów nadzorczych zapobiegających np. tzw. upadłościom reżyserowanym, których celem jest realizowanie interesów partykularnych niezgodnych z interesem przedsiębiorstwa czy jego właścicieli.

${ }^{9}$ Nawiązujemy tu do terminologii związanej z teorią agencji.

${ }^{10}$ Przykładem działania oportunistycznego może być dążenie do zawyżania szacunków masy upadłościowej czy przedłużanie procedury likwidacyjnej, co wywiera korzystny wpływ na wysokość wynagrodzenia.

${ }^{11}$ Analiza bardziej szczegółowych relacji pomiędzy sędzią komisarzem a syndykiem, analogiczna pod pewnymi względami do relacji organ nadzoru - menedżer, może być prowadzona w kategoriach teorii agencji.
} 
wielu czynników i w zasadzie konkretny ich układ determinuje zachowanie kontrahenta upadającego przedsiębiorstwa - może być on zarówno mocno zainteresowany wspomożeniem upadającego przedsiębiorstwa (bynajmniej do momentu ukończenia kontraktu) lub całkowicie niezainteresowany losem przedsiębiorstwa, w przypadku możliwości i łatwości dokonania zmiany kontrahenta. Charakter i siłę pojawiających się motywacji u dostawców i odbiorców kojarzyć można m.in. ze strukturą rynku, fazą zaawansowania kontraktu, unikalnością czy poziomem technologicznym dostaw.

Państwo pod postacią Skarbu Państwa, ministerstw czy innych instytucji państwowych angażuje się z reguły w postępowania upadłościowe wielkich korporacji ze względów ekonomicznych lub/i społecznych. Upadek gigantów (np. GM w USA) zagrażać może powstaniem „domina upadłości”, co negatywnie mogłoby wpływać na stan całej gospodarki, wzrost bezrobocia, niezadowolenia społecznego itp. Wobec tej sytuacji państwo staje zazwyczaj „po stronie upadającego”. Podejście to, jakkolwiek budzi szereg dyskusji i kontrowersji, jest w zasadzie powszechnie stosowane. Towarzyszy temu nie tylko syndrom „za duży, żeby upaść”, lecz także syndrom „zbyt powiązany, zbyt zglobalizowany, żeby upaść” (Mączyńska, 2015a).

Władze lokalne zainteresowane są utrzymywaniem „przy życiu” upadłych przedsiębiorstw, co wynika $\mathrm{z}$ dążenia władz do zmniejszania poziomu bezrobocia w regionie. Likwidacja przedsiębiorstw pociąga $\mathrm{z}$ reguły za sobą również upadłość mniejszych kooperantów, co zwiększa skalę problemów gospodarczych regionu. Spadają bowiem wpływy do budżetów lokalnych i zwiększa się poziom ubóstwa. Formami wsparcia udzielanego upadającym przedsiębiorstwom przez władze lokalne są: dotacje, subsydia, ulgi czy obniżanie podatków lokalnych

Pracownicy są zainteresowani istnieniem przedsiębiorstwa bankruta, mając nadzieję na utrzymanie swych miejsc pracy.

Wierzyciele - najważniejsze jest dla nich jak najszybsze odzyskanie możliwie jak najwyższej kwoty wierzytelności. Ze względu na występowanie różnych klas uprzywilejowania i wysokość zagrożonych wierzytelności siła tej motywacji może być różna.

Sądy i sędziowie komisarze - działanie sądów i siła motywacji sędziów do efektywnego odgrywania przewidzianej dla nich roli determinowana jest w istocie jakością systemu oceny ich pracy. Dobór odpowiednich kryteriów oceny efektywności postępowania upadłościowego wraz z odpowiednim systemem stymulacji materialnej i pozamaterialnej stanowi w tym przypadku kwestię o znaczeniu fundamentalnym ${ }^{12}$. Sąd i sędziowie stosują obowiązujące prawo, co jednak niewątpliwie ogranicza możliwość wprowadzania w pełni menedżerskiego podejścia do tworzenia systemu motywacji. Sądy i sędziowie stają nierzadko wobec dylematów wynikających z faktu, że dostrzegają oni niedostosowanie obowiązujących regulacji prawnych do konkretnie rozpatrywanych sytuacji.

Instytucje rządowe (urzędy skarbowe, ZUS) dbają o interes państwa głównie przez ściąganie należności podatkowych przedsiębiorstwa. Podobnie jak w przypadku sądów „stosują one prawo", choć mają większy zakres swobody w jego stosowaniu. W swych działaniach mogą zatem kierować się w większym stopniu „logiką ekonomiczną” niż „ślepą egzekucją” prawa przy ściąganiu należności.

Audytorzy, przedsiębiorstwa doradcze, kancelarie prawne i podatkowe itp. kierują się w swych działaniach przepisami prawa oraz wypracowanym prestiżem i etyką zawodową. Działają w zasadzie w sposób „bezstronny”, jakkolwiek i w stosunku do nich odnosi się

\footnotetext{
${ }^{12}$ Przykładowo, przyjęcie jako podstawowego kryterium oceny liczby prowadzonych czy zakończonych postępowań upadłościowych może powodować, że sąd będzie preferował „mniejsze” upadłości kosztem „większych”, co może mieć odzwierciedlenie w jakości postępowań przy „dużych upadłościach”.
} 
przytaczana już powyżej teoretyczna teza o powszechności oportunizmu w praktycznym postępowaniu ludzi. Rezultaty ich pracy mają bardzo duże znaczenie, gdyż w procesie upadłościowym stanowią podstawę, na której sąd opiera swe decyzje. W zakres działań tej grupy interesariuszy wchodzi sporządzanie i dokonywanie weryfikacji sprawozdań finansowych, dokonywanie wycen, orzekanie o sytuacji prawnej itp. Koszty tych prac mogą stanowić znaczące części kosztów z procedury upadłościowej.

Urzędy statystyczne generują i dostarczają informacje związane z oceną kondycją całej gospodarki lub określonej branży. Nie kierują się „żadnym” interesem własnym.

Liczba uczestników postępowania upadłościowego, jak wynika z przedstawionego wyżej niepełnego zestawienia, jest znacząca. Każdy z uczestników (interesariusz) kieruje się w swych działaniach „własnym interesem”, który może być zbieżny lub rozbieżny z interesami pozostałych uczestników tegoż postępowania. Niektóre z wymienionych podmiotów dążą do realizacji celów ambiwalentnych - zarówno ekonomicznych, jak i społecznych.

\section{Instytucja upadłości w polskiej gospodarce}

Skala zjawisk upadłości w Polsce, zarówno w ujęciu regionalnym, jak i na tle tego zjawiska w innych krajach stanowi przedmiot licznych publikacji ${ }^{13}$, a także szczegółowych statystyk w postaci sprawozdania w sprawach upadłościowych i naprawczych według właściwości rzeczowych publikowanych przez Ministerstwo Sprawiedliwości, GUS, Bank Światowy - raport Doing Business oraz instytucji komercyjnych, takich jak Centralny Ośrodek Informacji Gospodarczej, Coface Poland, Korporacja Ubezpieczeń Kredytów Eksportowych i inne ${ }^{14}$. Nie wydaje się zatem konieczne przytaczanie w tym względzie szczegółowej ilustracji tego zjawiska. Z uwagi na charakter prezentowanego artykułu autorzy chcieliby jedynie w zakończeniu przedstawić syntetyczną ocenę tej instytucji.

Badania prowadzone pod kierunkiem prof. E. Mączyńskiej wskazują, że instytucja upadłości w Polsce jest niskiej jakości. Autorzy tych badań stwierdzają m.in., że „upadłością nie są [...] zainteresowani wierzyciele - kalkulują bowiem czas, koszty postępowań oraz możliwość odzyskania wierzytelności. Dłużnicy pomimo prawnego obowiązku nie składają wniosków o ogłoszenie upadłości, a sankcje wobec nich nie są egzekwowane” (Babiarz-Mikulska, Czarpacka, Morawska, 2012).

Sądowy model rozstrzygania sporów i konfliktu interesów w postępowaniach upadłościowych nie jest efektywny ze względu na wysoki poziom formalizmu i brak bodźców do szybkiego kończenia postępowań. Sąd i sędzia komisarz są agentami wierzycieli reprezentującymi ich interesy. Zobligowani są oni do ścisłego przestrzegania reguł postępowania upadłościowego, co w niektórych przypadkach może być źródłem nieefektywności działań. Podstawowym miernikiem oceny i ewentualnych stymulacji finansowych sądu i sędziego komisarza (podobnie jak nadzorcy i syndyka) jest przede wszystkim, co jest całkowicie zrozumiałe,

${ }^{13}$ Zob. Zmiany strukturalne grup podmiotów gospodarki narodowej w rejestrze REGON (2014); Informacje i opracowania statystyczne GUS (2015); Antoniewicz (2010); Mazurek (2009, 2013).

${ }^{14}$ https://isws.ms.gov.pl/Data/Files/_public/isws/jednoroczne/2014/spr_zbior_2014/ms-s20un_2014; pdffile://C:/Users/admin/Desktop/Resolving\%20Insolvency\%20-\%20Doing\%20Business\%20-\%20World\%20Bank\%20 Group.htmhttp://www.coig.com.pl/lista-upadlosci-firm.php; http://www.kuke.com.pl/upadlosci_firm.php;www. krpu.pl; http://www.coface.phttp://www.egospodarka.pl/129143,upadlosci-firm-w-polsce; http://www.windykacja. pl/raporty,wzrost-liczby-upadlosci-polskich-przedsiebiorstw; http://www.eulerhermes.pl/analizy-ekonomiczne/economic-publications/Pages/Raporty-o-upad\%C5\%820\%C5\%9Bciach.aspx. 
przestrzeganie procedur prawa, nawet w sytuacji oczywistego braku logicznego uzasadnienia ich stosowania (np. przesłuchanie 15 tys. świadków czy „równe” proceduralnie traktowanie dłużnika zgłaszającego wierzytelność w kwocie 57 zł i 2 mln zł, wielokrotne korekty list wierzytelności). Sąd i sędzia rozliczani są przede wszystkim z przestrzegania przepisów proceduralnych, a w zdecydowanie mniejszym stopniu z szybkiego i „efektywnego” kończenia postępowań. Podobnie ma się rzecz z syndykami. Wskazuje to na potrzebę usprawnienia działania instytucji upadłości.

Profesor Morawska dowodzi, że instytucja upadłości w Polsce oparta jest z jednej strony na anachronicznych, sztywnych regulacjach prawnych, wymuszających automatyzm w podejmowaniu decyzji o upadłości, z drugiej zaś strony jej trzon stanowi zbiurokratyzowana organizacja wymiaru sprawiedliwości. Sądownictwo upadłościowe zostało ukierunkowane na przestrzeganie reguł proceduralnych, a nie na racjonalność ekonomiczną rozstrzygnięcia (Morawska, 2013).

Według prof. Mączyńskiej w Polsce wyraźny jest niedorozwój instytucjonalnej, tzn. sądowej, badawczej czy informacyjnej, infrastruktury upadłości. Tym uzasadnia ona postulat szerszego wykorzystywania $\mathrm{w}$ praktyce modeli wczesnego ostrzegania przed zagrożeniami w biznesie oraz postulat rozwoju instytucjonalnej infrastruktury upadłości, ukierunkowanej na monitoring upadłości i przeciwdziałanie jej. Jest to istotne tym bardziej, że współcześnie funkcjonowanie przedsiębiorstw charakteryzują rosnące napięcia, rosnący stopień ryzyka i niepewności, co skutkuje rosnącym zagrożeniem upadłością (Mączyńska, 2014).

Pomimo rosnącej w gospodarce globalnej złożoności powiązań gospodarczych przedsiębiorstw i ich „usieciowienia” oraz istnienia zjawiska efektu domina bankructw w Polsce nie istnieje ośrodek, który zajmowałby się badaniem tej problematyki kompleksowo i interdyscyplinarnie (Mączyńska, 2011). Ośrodki badań bankructw istnieją w innych krajach. Szczególnie pouczające są doświadczenia USA, gdzie istnieje Instytut Bankructwa - The American Bankruptcy Institute (ABI), utworzony w 1982 r. w celu zapewnienia obiektywnych analiz dotyczących upadłości. Zrzesza on ponad 11500 adwokatów, licytatorów, syndyków, bankierów, sędziów, kredytodawców, profesorów, księgowych i innych specjalistów. ABI stanowi centrum edukacji badań i rozwoju wiedzy na temat upadłości, którego osiągnięcia są regularnie publikowane (Mączyńska, 2009).

Na brak w Polsce takiego typu jednostek analitycznych nakładają się białe plamy w statystyce upadłości. Jakkolwiek istnieją statystyki ilościowe, brak jest kompleksowych statystyk i pogłębionych analiz ekonomiczno-finansowych dotyczących problemów upadłości przedsiębiorstw (Mączyńska, 2014). Potrzeba tworzenia tego typu baz danych staje się również coraz bardziej widoczna, gdyż coraz bardziej złożone struktury grup kapitałowych implikują to, że bankructwo jednego z przedsiębiorstw grupy może z jednej strony wywołać łańcuch upadłości, a z drugiej może być kamuflowane i ukrywane w skomplikowanej, gęstej sieci powiązań biznesowych, co nie sprzyja jasności i jednoznaczności dostarczanych przez rynek sygnałów.

\section{Zakończenie}

Współczesna teoria ekonomii, zarówno w ujęciu mikro, jak i makro, zaczyna przykładać coraz większe znaczenie do ról odgrywanych przez instytucje formalne i nieformalne oraz otoczenie instytucjonalnego procesów gospodarczych (Gruszecki, 2008). Dlatego też takie podejście powinno zostać uwzględnione przy opracowywaniu zasad prowadzenia postępowań upadłościowych. Odgrywa to niezwykle doniosłą rolę dla właściwego kształtowania przebiegów 
procesów gospodarczych, w tym zjawisk upadłości, które stanowią istotny element tych procesów.

Gospodarka dysponuje ograniczonymi zasobami, które mogą mieć alternatywne zastosowania w przypadku niepowodzenia działalności gospodarczej w niektórych jej podmiotach. Dlatego ważne jest istnienie systemu prawnego wymuszającego prowadzenie uczciwych i efektywnych z punktu widzenia ekonomicznego postępowań upadłościowych i naprawczych, które są neutralnymi instrumentami „oczyszczającymi” obrót gospodarczy z niewypłacalnych przedsiębiorstw. Znaczenie instytucji upadłości w gospodarce rynkowej polega zatem na tym, że jej sprawne działanie wpływa pozytywnie na wzrost gospodarczy i rozwój społeczno-ekonomiczny. Upadłość to jedna z najważniejszych instytucji gospodarki rynkowej. Prawidłowo skonstruowana normatywnie i prawidłowo wdrożona instytucjonalnie gwarantuje skuteczną ochronę wierzycieli i efektywną alokację środków produkcji (Tokarski, 2015).

$\mathrm{Na}$ instytucje upadłości składają się zarówno regulacje prawne zawierające wytyczne dotyczące procedury, jak i cały aparat zapewniający realizację celów postępowań upadłościowych, który tworzą sędziowie orzekający w sprawach upadłościowych, syndycy zarządzający masą upadłości, nadzorcy sądowi, zarządcy. Upadłość przedsiębiorstw stanowi nieodłączny dla gospodarki rynkowej mechanizm selekcji nieefektywnych podmiotów gospodarczych. Niezwykle ważne staje się zatem to, aby system/procedury upadłościowe zapewniały sprawny i efektywny (w różnych wymiarach) przebieg tego zjawiska, co sprzyja rozwojowi przedsiębiorczości (Lee i in., 2011). Niezbędnym tego warunkiem, jak podkreśla E. Mączyńska, jest konieczność rozbudowy w Polsce nieadekwatnej obecnie do warunków gospodarowania szeroko rozumianej instytucjonalnej infrastruktury upadłości (Mączyńska, 2004).

Niedorozwój instytucjonalnej infrastruktury upadłości wiąże się w dużym stopniu z tym, że bankructwo to problem, który w Polsce nie został dostatecznie zdiagnozowany, a problematyka upadłości nie doczekała się zwartej, kompleksowej teorii (Mączyńska, 2013). Wynika to częściowo z ogromnego zróżnicowania i zmienności przyczyn bankructw i tego, że upadłości przedsiębiorstw nie stanowią centralnego elementu żadnego ze znanych nurtów teorii ekonomii. Brak teorii bankructwa jest coraz bardziej dotkliwie odczuwany w praktyce gospodarczej. Stąd też różne ośrodki podejmują wieloprzekrojowe badania, w których wyniku powstają pierwsze uogólnienia, syntezy, które można uznać za elementy stopniowo kształtującej się pozytywnej i normatywnej teorii bankructwa.

W przeszłości podejście normatywne ukierunkowane było przede wszystkim na zagwarantowanie wierzycielom niewypłacalnego przedsiębiorcy maksymalnego zaspokojenia ich wierzytelności. Obecnie większą wagę przywiązuje się do przywrócenia efektywności rynkowej przedsiębiorstw zagrożonych upadłością. Dlatego też w unormowaniach bankructwa preferuje się umożliwianie podejmowania działań naprawczych. Znajduje to swój wyraz w propagowaniu wobec upadających przedsiębiorstw tzw. polityki drugiej szansy.

Dostosowane do wymogów współczesnej gospodarki rozwiązania instytucjonalne, w tym instytucjonalno-ustrojowe, powinny sprzyjać racjonalizacji funkcjonowania przedsiębiorstw i przeciwdziałać ich upadłościom, zaś w przypadku ich wystąpienia łagodzić ich następstwa ekonomiczne i społeczne. 
Literatura

References

Adamska, A., Mączyńska, E. (red.). (2013). Upadłości, bankructwa i naprawa przedsiębiorstw. Wybrane zagadnienia. Warszawa: SGH.

Antoniewicz, P. (2010). Procesy upadłościowe przedsiębiorstw w Polsce. Raport z badań, KPF w Polsce. Warszawa-Gdańsk.

Babiarz-Mikulska, K., Czapracka, A., Morawska, S. (2012). Ocena efektywności procedur upadłościowych wobec przedsiębiorców. Aspekty prawne, ekonomiczne i organizacyjne. Warszawa: Difin.

Bauer, K. (2009). Wiarygodność informacji tworzonych przez jednostki w stanie upadłości likwidacyjnej. W: pracownicy Katedry Rachunkowości SGH (red.), Problemy współczesnej rachunkowości. Warszawa: SGH.

Bliss, R.R. (2003). Bankruptcy law and large complex financial organization: A primer. Federal Reserve Bank of Chicago, Economic Perspectives, 48(1Q), 48-58.

Collins, J. (2015). Jak upadaja giganci. Warszawa: MT Biznes.

II szansa dla przedsiębiorców. Raport z badań (2011). Warszawa: PARP.

Flaga-Gieruszyńska, K. (2012). Prawo upadłościowe i naprawcze. Warszawa: C.H. Beck.

Gaweł, T., Klimczak, M. (2005). Pojęcie instytucji w prawie i ekonomii. W: B. Polszakiewicz, J. Boehlke (red.). (2005). Ład instytucjonalny w gospodarce. Toruń: UMK.

Gruszecki, T. (2008). Instytucjonalne aspekty w teorii przedsiębiorstwa. W: E. Mączyńska (red.), Bankructwa przedsiębiorstw. Wybrane aspekty instytucjonalne. Warszawa: SGH.

Gurgul, S. (2010). Prawo upadłościowe i naprawcze - komentarz. Warszawa: C.H. Beck.

Informacje i opracowania statystyczne GUS (2015). Warszawa: GUS.

Lee, S.-H., Yamakawa, Y., Peng, M., Barney, J. (2011). How do bankruptcy law affect entrepreneurship development around the world? Journal of Business Venturing, 26.

Lewandowski, R., Wołowski, P. (2014). Prawo upadłościowe i naprawcze. Warszawa: C.H. Beck.

Łodzianna, A., Makuch, B. (2005). Upadłość likwidacyjna. Praktyczny poradnik dla syndyków. Warszawa: Difin.

Marszałkowska-Krześ, E., Gil, I. (2011). Postępowanie w sprawach upadłościowych i rejestrowych. Warszawa: Wolters Kluwer Polska.

Mazurek, S. (2009). Liczba wniosków o upadłość jako miara zjawiska upadłości w Polsce. W: D. Zarzecki, Zarządzanie finansami: aktualne wyzwania teorii i praktyki. Zeszyty Naukowe Uniwersytetu Szczecińskiego, 533.

Mazurek, S. (2013). Statystyka upadłości podmiotów biznesowych. W: D. Zarzecki, Zarządzanie finansami: mierzenie wyników przedsiębiorstw i ocena efektywności inwestycji. Zeszyty Naukowe Uniwersytetu Szczecińskiego, 760, 201-210.

Mączyńska, E. (2009). Meandry upadłości przedsiębiorstw. Klęska czy druga szansa? Warszawa: SGH.

Mączyńska, E. (2011). Bankructwa przedsiębiorstw a nadzór właścicielski. W: E. Mączyńska (red.), Cykle życia i bankructwa przedsiębiorstw. Warszawa: SGH.

Mączyńska, E. (2012). Ekonomiczno-instytucjonalne uwarunkowania bankructw i upadłości. W: S. Morawska (red.), Ekonomia i prawo upadłości przedsiębiorstw. Warszawa: SGH.

Mączyńska, E. (2013). Wprowadzenie. W: E. Mączyńska (red.), Procesy upadłościowe i naprawcze w Polsce na tle doświadczeń Unii Europejskiej. Warszawa: SGH.

Mączyńska, E. (2014). Bankructwa przedsiębiorstw. Wybrane aspekty ekonomiczne i prawne. Warszawa: SGH.

Mączyńska, E. (2015a). Wprowadzenie. W: E. Mączyńska (red.), Bankructwa, upadłości i procesy naprawcze przedsiębiorstw. Wybrane aspekty regulacyjne. Warszawa: SGH.

Mączyńska, E. (2015b). Wprowadzenie. Biuletyn PTE, 1.

Mączyńska, E., Morawska, S. (2015). Efektywność procedur upadłościowych. Warszawa: SGH. 
Morawska, S. (red.). (2011). Modele postępowań upadłościowych w Polsce i wybranych krajach UE. Warszawa: Wiedza i Praktyka.

Morawska, S. (2013a). Efektywność oraz skuteczność postępowań upadłościowych na tle praktyki sądowej - perspektywa wierzycieli, Biuletyn PTE, 1 .

Morawska, S. (2013b). Przedsiębiorca w obliczu upadłości. Warszawa: SGH.

Morawska, S., Roszkowska, P. (2011). Interesariusze w procesie upadłości przedsiębiorcy. Kwartalnik Nauk o Przedsiębiorstwie, 2.

North, D. (1991). Institutions. Journal of Economic Perspectives, 1.

Podel, W., Olszewska, M. (2012). Upadłość w praktyce. Warszawa: Difin.

Prusak, B. (2012). Charakterystyka procesów upadłościowych przedsiębiorstw w Polsce. W: B. Prusak (red.), Przedsiębiorstwo w czasach kryzysu. Gdańsk: Politechnika Gdańska.

Stankiewicz, W. (2012). Ekonomika instytucjonalna, Zarys wykładu. Warszawa: PWSBiA.

Stiglitz, J.E. (2005). Globalizacja. Warszawa: Wydawnictwo Naukowe PWN.

Świeboda, Z. (2003). Prawo upadłościowe i naprawcze, Komentarz. Warszawa: Lexis Nexis.

Tokarski, A. (2015). Kierunki ewolucji systemu upadłościowego w Polsce. Przedsiębiorczość - Edukacja, 11.

Tokarski, A. Tokarski, M. (2013). Conflicts of participants in insolvency proceeding. W: Globalizacja a jej socjalno-ekonomicke dosledky. Żilina: Żilinska Univerzita.

Tokarski, A., Tokarski, M. (2014). Models of bankruptcy system in Poland - characteristics, 14th International Scientific Conference under the Auspices of Ministry of Finance of the Slovak Republic, Žilina: University of Žilina.

Ustawa z dnia 23 lutego 2003 r. Prawo upadłościowe i naprawcze (Dz.U. z 2009 r. Nr 175, poz. 1361).

Ustawa $z$ dnia 15 maja 2015 r. Prawo restrukturyzacyjne (Dz.U. z 2015 r., poz. 978).

Wardzińska, E. (2013). Syndyk jako zarządca i likwidator w postępowaniu upadłościowym w Polsce. W: A. Adamska, E. Mączyńska (red.), Upadłości bankructwa i naprawa przedsiębiorstw. Wybrane zagadnienia. Warszawa: SGH.

Zedler, F. (2009). Prawo upadłościowe i naprawcze w zarysie. Warszawa: Wolters Kluwer Polska.

Zmiany strukturalne grup podmiotów gospodarki narodowej w rejestrze REGON (2014).

Andrzej Tokarski, dr nauk ekonomicznych, adiunkt w Katedrze Finansów i Rachunkowości Wyższej Szkoły Bankowej w Toruniu. Jego zainteresowania badawcze koncentrują się na zagadnieniach związanych z oceną kondycji ekonomiczno-finansowej podmiotu gospodarczego w aspekcie zagrożenia kontynuacji działalności oraz upadłością przedsiębiorstw w gospodarce rynkowej. Autor lub współautor ok. 100 publikacji z zakresu rachunkowości, analizy finansowej i finansów przedsiębiorstw.

Andrzej Tokarski, $\mathrm{PhD}$ in economics, an employee of the Department of Finance and Accounting of the School of Banking in Torun. His research interests focus on issues related to the assessment of economic and financial economic operator in terms of business continuity risks and bankruptcy of enterprises in the market economy. Author or co-author of about 100 publications in the fields of accounting, financial analysis and corporate finance.

\section{Adres/Address:}

Wyższa Szkoła Bankowa w Toruniu

Katedra Finansów i Rachunkowości

ul. Młodzieżowa 31A

87-100 Toruń, Polska

e-mail: andrzej.tokarski@wsb.torun.pl

Marek Matuszak, dr nauk ekonomicznych, adiunkt w Katedrze Zarządzania Wyższej Szkoły Bankowej w Toruniu. Jego zainteresowania badawcze skupiają się wokół zagadnień transformacji polskich przedsiębiorstw oraz wokół upadłości przedsiębiorstw. Autor lub współautor ponad 40 publikacji naukowych. 
Marek Matuszak, PhD in economics, an employee of the Department of Management in the School of Banking in Torun. His research interests focus on issues related to the transformation of Polish enterprises and enterprises bankruptcy. Author or co-author of over 40 scientific publications.

\section{Adres/Address:}

Wyższa Szkoła Bankowa w Toruniu

Katedra Zarządzania

ul. Młodzieżowa 31A

87-100 Toruń, Polska

e-mail: marek.matuszak@wsb.torun.pl

Artykuł powstał w ramach projektu badawczego zatytułowanego Uwarunkowania upadłości przedsiębiorstw województwa kujawsko-pomorskiego $z$ uwzględnieniem oceny efektywności procedur upadłościowych, finansowanego ze środków statutowych nr 73/2014 WSB w Toruniu. 